\title{
Public Policies for Procurement under COVID19
}

\author{
Luís Valadares Tavares Pedro Arruda
}

\begin{abstract}
Public procurement is a main issue in the frontline of Governments fighting COVID 19 pandemic as the need for additional and urgent acquisitions as well as the need to consolidate the supply chains and to promote sustainable and innovative procurement have been a source of deep changes and main challenges disturbing public markets and invalidating several assumptions of the traditional public contracting.

In this paper, the development of appropriate public policies to cope with these challenges is studied following the approach suggested by several authors and including four stages: a Stage on Facts and Issues where the main challenges and conditions are studied, the Options Stage to describe which polices and procedures can be adopted, a Values Stage stating the main values to be pursued and, finally, a Policies Stage including the selection of the recommended policies.

The analysis of the challenges and facts includes the study of a taxonomy of short and longer term needs and the available options are based on the comparative study of procedures ruled by the European Directives on Public Procurement approved on 2014. The major values to be respected include the principle of competition which is a major institutional principle of the European Treaty and of the Directives as well as the goal of promoting sustainable and innovative public procurement.
\end{abstract}

Several indicators are suggested to describe the application of the public procurement policies adopted across EU and their comparative analysis is presented using the TED data for contracts concerning COVID 19.

The case of Portugal is discussed and final remarks about the recommended public policies are also included herein.

\section{Keywords}

COVID19; public policies; procurement; European Directives; urgency; sustainability; innovation.

\section{COVID 19: Public Procurement Challenges}

Since the pandemic started early 2020, health public authorities are having to acquire a wide spectrum of diversified goods, services and works with a world value of about 1 trillion of dollars per month (Gaspar et al., 2020) justifying multiple procurement decisions and legal changes in most European States.

Most of these acquisitions fall under the class of commercial public markets according to the taxonomy proposed by (Sanchez Graells, 2015) but their nature and required calendar are quite heterogeneous as they include four different classes:

a) additional hospital beds to avoid hospital congestion;

b) specialized equipment for acute hospital treatment such as ventilators for intensive care units;

c) consumer goods and services for COVID19 disinfection; 
d) standard products like COVID 19 tests or Individual Protection Equipment (IPE)including masks, examination gloves, goggles, etc.

Therefore, it is widely recognized that "the impacts of chosen procurement strategies have an immediate effect on the effectiveness of policies for dealing with the pandemic and its social and economic consequences."(OECD, 2020a) but the procurement challenges are quite different for these four classes because:

a) The increase of the hospital capacity may imply the acquisition of campaign installations through quick awarding of integrated contracts including design, equipment, materials, works, finishings, etc.. The number of these contracts tends to be very small in each State and so special rules to cope with them can be approved and used.

b) These equipments should be subject to very detailed specifications and a stage of qualification of candidates is very convenient. It should be noted that most of them are not just useful for this pandemic as their needs will last for long periods and so a longer term perspective is required as it happens with the equipments of intensive care units.

c) However, if capacity is short and there is the risk of being exceeded at short term, an urgent acquisition may be justified but, if so, adequate and coordinated procurement is vital to avoid an unbalanced game giving speculative power to the suppliers.

d) These acquisitions have a basic or standardized nature and should be repeatedly executed during many months. Actually, the world monthly consumptions of medical masks, examination gloves and goggles due to COVID 19 were estimated by WHO equal to $89 \mathrm{M€}, 76 \mathrm{M€}$ and 1.6 M€, respectively (World Health Organization, 2020).

Therefore, the nature of policy options and legal measures which should be adopted have to respect this diversity and avoiding the typical mistake of wrapping up all these acquisitions as a homogeneous package. Such mistake stems also from the common tradition of classifying the contract object just in terms of goods, services and works which was quite appropriate during the fifties but hardly applicable presently due to the ubiquitous trend of increasing technological complexity and market diversity. Who ignores that buying tonnes of apples requires a very different approach than buying highly performing ventilators?

The acquisitions of type $\mathrm{A}$ are quite rare and so special attention is given in this paper to the other 3 classes.

Therefore, and under this "war scenario", a major policy issue concerns the selection of the most appropriate public policies to be adopted by Governments to cope with these new procurement needs justifying the formulation of the research question presented in the next section and studied in this paper.

\section{Research Question and Methodology}

An unexpected global event with dramatic health, social and economic impacts, as it happens with COVID19, is always a major challenge for Governments as they are tempted to cope with such challenges through unplanned, non-sustainable and myopic decisions with the single purpose of acting fast and therefore the research question addressed by this paper is: 
Can the public contracting authorities cope with the needs of procurement due to COVID 19 respecting the principles as well as the rules of the 2014 EU Directives of Public Procurement (European Parliament and the Council of the European Union, 2014a) and pursuing sustainable and innovative public policies avoiding fragmented and myopic options?

The adopted methodology in this paper follows the principles of public policy research already proposed by key authors since the fifties (see, namely, (Lasswell, 1951)) and respecting its interdisciplinary nature (DeLeon and Vogenbeck, 2007) to integrate the contributions of Economics, Public Management, Law and Digital Technologies (Tavares, 2013). The adopted approach follows the "problem oriented" and systemic methodology proposed and studied by (Ackoff, 1974) (Simeon, 1976) (Tavares et al., 1997) as well as (Dunn, 2015) and it is applied in this paper through a four stage process (Fischer et al., 2017) taking into consideration the special impacts of adversity (Dror, 2017):

a) Formulation of the needs, conditions and challenges to be addressed: Facts and Issues Stage.

b) Scenarios and options design to enlarge the space of alternatives: Options Stage.

c) Values and goals to be pursued: Values Stage.

d) Evaluation and policies recommendations: Policies Stage.

The study of the procurement needs is presented in the next section (Facts Stage) identifying the short and long term needs and the available options according to the EU Directives of Public Procurement are studied in Sections 3 and 4 concerning the urgent and the long term needs (Options Stage). The Values Stage and the Policies Stage are studied for the two major goals to be addressed - competitive as well as sustainable and innovative public markets - in Sections 5 and 6. A cross-State comparative analysis of the application of the selected policies using the proposed indicators (Sections 5 and 6) is presented in Section 7 and the case-study of Portugal is discussed in the Section 8. Final remarks are included in the last section.

\section{Short and Long Term Needs, Conditions and Challenges}

The short term needs are quite well known as they include most of the items of types B, C and D to cope with the sudden increase of health services due to COVID19. However, in a period of drastic changes of needs and increased demand for items of classes B, C and D, the supply chains tend to be disturbed or even collapsed creating opportunistic sales, lack of compliance and shortage restrictions. This is clearly diagnosed by (Lalliot and Yukins, 2020) concluding that:

'the crush of the pandemic also transformed a buyers' public procurement market into a sellers' market and forced those government buyers to compete bitterly with one another-disruptions which shook fundamental assumptions that traditionally shaped the norms and rules of public procurement".

Many public markets are often considered as a total or partial monopsony but now the power is being transferred for the sellers due to scarcity of supplies and to doubts about compliance with quality standards. This is clearly shown by the unjustified increase of prices in international markets as it is well documented by the case presented by one of the most important public hospital groups in Portugal, the CHOC ("Centro Hospitalar de Lisboa Ocidental ", CHLO ) with an annual budget of $200 \mathrm{M}$ euros , 5000 staff members and 300 beds for COVID 19 comparing the unit price (euros) offered in international markets for the acquisition of the same critical goods in 2019 and 2020 (Peres, 2021). 
Table 1- Critical goods prices

\begin{tabular}{|c|c|c|c|}
\hline & $\begin{array}{c}\text { Price (per unit) } € \\
2019\end{array}$ & $\begin{array}{c}\text { Price (per unit) } € \\
2020\end{array}$ & $\begin{array}{c}\text { Price } \\
2020 / 2019\end{array}$ \\
\hline Masks & 0.03 & 0.13 & 4.33 \\
\hline Gloves & 0.10 & 0.32 & 3.20 \\
\hline Gowns & 0.36 & 2.10 & 5.83 \\
\hline
\end{tabular}

Therefore, the price speculation or scarcity of supplies can also increase the risk of lack of integrity as it is noted by (Schultz and Søreide, 2008) and (OECD, 2020b) including the following remark:

"Given market dominance, many transactions are taking place off-book, and price volatility is extreme, with often significant advance payments required by vendors. This could contribute to a paradigm shift in corrupt schemes, as buyers could now corrupt sellers in order to receive essential goods and services --the reverse of what normally happen"

This context of scarcity can also imply changing of contract terms meaning that public procurement has also to cope with market uncertainty. Such uncertainty is not compatible with the most traditional approach of Administrative Law assuming that there is full reliable information and supply availability to buy goods or services "from the shelf" (Tavares, 2017) (Tavares, 2018).

This lack of understanding about these new challenges can explain many quoted examples of failures such as masks without proper certification or ventilators that could not be used as it happened in Portugal (for instance, 30 ventilators were bought by 1,3 Million euros and they have never been used due to the lack of functionalities (Público, 2020)).

Therefore, a major need is the proactive search for better knowledge about markets features, contacting the economic operators to be better informed about their options and inventories as well as inquiring about their potential interest to be engaged into longer term sustainable and innovative initiatives.

This means that this pandemic is also an opportunity to promote sustainable and innovative procurement (Tavares, 2019) (European Commission, 2020a) according to the paradigm of demand driven innovation (Edquist et al., 2000) which has been extensively studied by OECD (OECD, 2011) :

"This interest in demand-side innovation policy has emerged as part of a greater awareness of the importance of feed-back linkages between supply and demand in the innovation process" (OECD, 2011)

and then each Government can become "market shaper-not only market fixer"(Mazzucato, 2016).

Thus, the procurement needs due to COVID 19 go much further than the widely publicized objective of "buying fast" implying the approval of the so called "fast law" (Tavares, 2020).

Conversely, maximal priority should be also given to the adoption of proactive policies promoting longer term sustainable and innovative procurement as well as the consolidation of supply chains 
of critical goods and services which will have to be procured for months or years helping to fight COVID19 and to revamp the social and economic recovery.

A typical example concerns the procurement of computers for the students so that they can be served by e-learning due to the confinement rules as this vast need can be used to develop long term procurement strategies including the promotion of sustainable products, namely using a higher percentage of recycled materials or consuming less energy, as well as the development of innovative features, for instance adapting the features to the specific requirements of e-learning. Alternatively, this acquisition can be formulated as an urgent shopping from the shelf, without any advanced planning and then the results are quite obvious: lower value for money and collapse of the supply chains without timely deliver. Unfortunately, this failure is happening in Portugal where the acquisition of computers to be used by about 1 million students was promised by the Prime Minister on 11 April 2020, but the procurement was just started in the last quarter of 2020, without any planning, and so most of the computers were not yet delivered on February 2021 (Expresso, 2021) although all students should be now attending classes and being served by elearning.

The European Commission has approved an important communication (European Commission, 2020a) concerning public procurement due to COVID 19 and this policy line promoting innovative and sustainable procurement is clearly recommended:

“(..)Interaction with the market may offer good opportunities to take into account also strategic public procurement aspects, where environmental, innovative and social requirements, including accessibility to any services procured, are integrated in the procurement process." (bolded by the author)

Furthermore, other special measures can be adopted helping contractors to execute contracts through advanced payments or other financial measures and they can have significant benefits not just for the economic and social conditions but also to increase the rate of success of contracts awarded by contracting authorities and their value for money. Another important need for public procurement under COVID 19 concerns the financial assistance to economic operators to help them executing the contracts through advanced payments or other financial measures .

Some authors (Gaspar et al., 2020) estimate that world nations have allocated about US $\$ 2.6$ trillion/month to relief packages with fiscal support or credit and equity injections and the European Commission approved a Framework (European Commission, 2020b) allowing a set of financial measures, grants and loans, to help economic operators to overcome COVID 19 challenges and this policy line should be integrated with the policy lines concerning public procurement.

Summing up, public procurement should play a central role in public policies to fight COVID19 and the needs concerning the items of types B,C and D include two types:

Type I: Emergency, occasional and non-repetitive acquisitions to be accomplished quickly and executed in very short periods of time.

Type II: Long term acquisitions lasting for months or even years requiring a stable and coordinated strategy to improve sourcing through innovation and sustainable policies in order that quality, innovation and efficiency of markets will be increased. 
Understanding these two types of needs require information and knowledge about public markets and public management so that the most appropriate procurement options will be adopted respecting the principles and rules of the European Directives of Public Procurement (European Parliament and the Council of the European Union, 2014a). Thus, and according to the presented methodology, the major options for type I and type II needs will be studied in the following two sections

\section{Public Procurement Options for Type I Needs}

The needs of Type I case may justify the adoption of urgent deadlines for procedures with prior publication of a notice as it is pointed out by (European Commission, 2020a) :

'Using an 'accelerated' open or restricted procedure complies with the principles of equal treatment and transparency and ensures competition even in cases of urgency"

The urgency deadlines are presented in Table 2:

Table 2 - Deadlines for Urgent Procedures

\begin{tabular}{|l|l|l|}
\hline Procedure & $\begin{array}{l}\text { Minimal Regular } \\
\text { deadlines }\end{array}$ & $\begin{array}{l}\text { Minimal Shortened } \\
\text { deadlines }\end{array}$ \\
\hline Open procedure & 35 days (14) & 15 days \\
\hline $\begin{array}{l}\text { Restricted procedure (step 1: Request for } \\
\text { participation) }\end{array}$ & 30 days (15) & 15 days (16) \\
\hline $\begin{array}{l}\text { Restricted procedure (step 2: Submission of } \\
\text { the tender) }\end{array}$ & 30 days (17) & 10 days (18) \\
\hline
\end{tabular}

However, in other urgent situations, these deadlines may be too long and so the negotiated procedure without prior publication of notice (NPWN) (see Article 32 of (European Parliament and the Council of the European Union, 2014a)) may be adopted but the quoted conditions should be respected (European Commission, 2020a):

“...)In the individual assessment of each case the following cumulative criteria will have to be fulfilled:

2.3.1. 'Events unforeseeable by the contracting authority in question'(...)

2.3.2. Extreme urgency making compliance with general deadlines impossible (...)

2.3.3. Causal link between the unforeseen event and the extreme urgency (...)

2.3.4. Only used in order to cover the gap until more stable solutions can be found."

Therefore, it is clear that NPWN should be not used during long or indefinite periods to cope with repetitive and similar procurement needs.

Quite often, the application of this exceptional procedure can justify doubts and criticisms as it is exemplified by the interesting discussion between Pedro Telles and Sanchez-Graells (SanchezGraells, 2020) about the legality of its application to the purchase by the British Government of 10000 ventilators as the former has doubts based on the previous British decision of not 
participating in a EU joint procurement agreement with same object and the doubts of the latter are based on the inadequate selection of the supplier.

These exceptional procedures can only be applied if competitive procedures with urgent deadlines are not acceptable and so, if at the time of award, the contractor is not capable to cope with the contract, as it seems to be the case, how can the adoption of NPWN can be justified?

The absence of appropriate justification for the adoption of NPWN can also increase the risk of lack of integrity which happens often in any emergency context as it is noted by (OECD, 2020b):

"While risks of fraud and corruption are always present in public procurement,1they are elevated in emergency procurement processes. Past health and humanitarian crises, such as Hurricane Katrina in 2005 or the Ebola outbreak in 2014-16, have shown how these processes can be abused at the expense of those most in need of said goods and services"

Therefore, the most appropriate selection of a procedure to cope with urgent needs should compromise urgency with competition, transparency and sustainability .Such challenging decision is studied in Section 6.

\section{Public Procurement Options for Type II Needs}

Fortunately, there also quite appropriate solutions to cope with type II needs based on the instruments for electronic and aggregated procurement included in (European Parliament and the Council of the European Union, 2014a), namely, Framework Agreements (FA) or Dynamic Purchasing Systems (DPS) including Electronic Catalogues (EDC), as they can provide quite efficient solutions as it is pointed out in 2.3.4 by (European Commission, 2020a) to promote sustainable and innovative procurement.

These techniques and instruments for electronic and aggregated procurement are ruled by the Directives on Public Procurement on 2014 (European Parliament and the Council of the European Union, 2014a) and require the adoption of electronic procurement which is mandatory since 2018 across EU.

These instruments imply an initial stage of qualification of economic operators and then an evaluation of submitted tenders by the qualified candidates to evaluate their tenders and to contract those with better tenders. Thus, the contracted economic operators become a "confined" market with a duration of up to 4 years (or 8 years in the case of the special sectors, (European Parliament and the Council of the European Union, 2014b)) which can be used every time a contracting authority included in the procedure has a specific need. This type of market is quite important in Public Management and it is called Quasi-Market (Le Grand and Bartlett, 1993) having been also treated by key legal authors such as (Vincent-Jones, 2006).

Such Quasi-Market is fixed for the Framework Agreements (FA) but newcomers can be qualified in DPS increasing competition and transparency.

It should be noted that the minimal times to receive applications and tenders either for FA or DPS follow the rules of the restricted procedure (Article $28^{\circ}$ ) and so in the case of urgency they can be reduced to 15 days (applications) or 10 days (electronic tenders), which means that these durations are similar to the usual periods adopted to invitation procedures.

Furthermore, the Article $36^{\circ}-4$ about Electronic Catalogues is quite clear about the possibility of awarding a contract in terms of the Electronic Catalogue obtained as an outcome of a FA (or of a 
DPS) which means that even the duration of 10 days can be avoided if no updated tender is required by the contracting authority:

"4. Where a framework agreement has been concluded with more than one economic operator following the submission of tenders in the form of electronic catalogues, contracting authorities may: (...)

(b) notify tenderers that they intend to collect from the electronic catalogues which have already been submitted the information needed to constitute tenders adapted to the requirements of the contract in question; provided that the use of that method has been announced in the procurement documents for the framework agreement."

Therefore, FA and DPS with an EC are particularly well adapted to the needs of Type II for items $\mathrm{B}, \mathrm{C}$ and $\mathrm{D}$ along months and years suffering the effects of pandemic because:

a) They permit setting up appropriate Quasi-Markets, respecting full competition and transparency and improving the value for money of each acquisition.

b) After being set up, they allow a very expeditious calendar including 15 days for the period of qualification and 10 or 0 (with an electronic catalogue) days to receive tenders.

c) They contribute to the coordination between contracting authorities and the aggregation of demand reducing the risk of suffering from speculative and opportunistic strategies developed by suppliers due to the increase of demand.

The Directives also include other procedures promoting innovation, namely the Partnership for Innovation (Article $31^{\circ}$ ) stating that:

"1-...In the procurement documents, the contracting authority shall identify the need for an innovative product, service or works that cannot be met by purchasing products, services or works already available on the market. It shall indicate which elements of this description define the minimum requirements to be met by all tenders. The information provided shall be sufficiently precise to enable economic operators to identify the nature and scope of the required solution and decide whether to request to participate in the procedure. The contracting authority may decide to set up the innovation partnership with one partner or with several partners conducting separate research and development activities.(..)

7-The contracting authority shall ensure that the structure of the partnership and, in particular, the duration and value of the different phases reflect the degree of innovation of the proposed solution and the sequence of the research and innovation activities required for the development of an innovative solution not yet available on the market "

Thus, this procedure (Gomes, 2021) can be particularly useful to achieve better solutions for products or services with a higher level of technological complexity such as ventilators, vaccines, or other drugs. Using this procedure is much more transparent and efficient to support the development of new products and services than the more traditional approach of allocating subsidies and grants through casual options and under debatable equity and transparency conditions.

Obviously, these options are even more useful if these long term procedures are opened before the occurrence of natural disasters ("preventive procurement ") as it has been suggested by several authors, namely after well known disasters as the KATRINA hurricane in USA (Yukins and Schwartz, 2005) (Schultz and Søreide, 2008) (Raimundo, 2012) but most Governments tend to 
ignore preventive public policies against unknown dangers because they may believe that such unfortunate challenges will not happen again.

\section{How to promote competition, sustainability and innovation using procurement options ?}

According to the presented methodology, the presented options should be now discussed in terms of the values to be pursued - Competition as well as Sustainability and Innovation - in order that the most appropriate options will be selected by the contracting authorities.

\section{A) Competitive public markets}

The European Union is based on the principles of Market Economy which have been revised to accommodate social policies by the Lisbon Treaty (European Union, 2012) as it is pointed out by (Gerbrandy et al., 2019) labeling the European economy as "Social Market Economy" considering the Article 3-3 of (European Union, 2012)

"The Union shall establish an internal market. It shall work for the sustainable development of Europe based on balanced economic growth and price stability, a highly competitive social market economy, aiming at full employment and social progress, and a high level of protection and improvement of the quality of the environment. It shall promote scientific and technological advance. ..."

These social objectives should respect the general principles of equality, transparency, proportionality and competition and so public procurement should also respect the principle of competition so much as possible as it is clear from the first recital of (European Parliament and the Council of the European Union, 2014a):

'The award of public contracts by or on behalf of Member States' authorities has to comply with the principles of the Treaty on the Functioning of the European Union (TFEU), ... so as to ensure that those principles are given practical effect and public procurement is opened up to competition ".

and ruled by the Article $18^{\circ}$ of (European Parliament and the Council of the European Union, 2014a)

"1. Contracting authorities shall treat economic operators equally and without discrimination and shall act in a transparent and proportionate manner. The design of the procurement shall not be made with the intention of excluding it from the scope of this Directive or of artificially narrowing competition. Competition shall be considered to be artificially narrowed where the design of the procurement is made with the intention of unduly favouring or disadvantaging certain economic operators.".

An interesting interdisciplinary interpretation of this article is presented in (Sanchez Graells, 2015).

Respecting this principle is also important because competitive procurement plays a key role to shape competitive markets and to form prices as it was studied by several authors such as (Caldwell et al., 2005) (Townsend, 1980). This is why disrespect this principle may be not just a violation of one of the EU institutional principles but it may be also a reason for intervention by authorities in charge of regulating competittion (Sanchez-Graells, 2018).

Furthermore, the lack of competitive public procurement is often correlated with bad practices of corruption and patronage even in countries with a general low level of corruption as it is shown for the case of Sweden (Broms et al., 2019). 
The basic concept of competition has an economic nature (Hunt, 2000) and the concept of competitive interaction between consumers and vendors is the key generator of value for money for the buyers as it is noted by (Prahalad and Ramaswamy, 2004):

"The new value creation space is a competitive space (...) developed through purposeful interactions between the consumer and a network of companies (...)".

This is why , according to the classical principles of the Theory of the Consumer in Market Economy (Allen, 1936), the expected consumer value of an acquisition is increased if the buyer carries out searching and comparative evaluations between alternative bids before buying and this is why competitive procedures should be adopted in public procurement, not just for increasing transparency and equity (ClientEarth, 2011) but also to increase the value for money for the buyer (Piga and Treumer, 2013). Furthermore:

"Majoritarian views advocate for an interventionist approach and instrumental utilization of procurement for the promotion of horizontal policies seen as deeply embedded in the Europe 2020 strategy. Conversely, public procurement can only make such a contribution by promoting the maximum degree of competition and being. open to market-led innovation"

as it is pointed out by (Sanchez Graells, 2016) which means that competition is a key attribute of public procurement if development horizontal public policies should be pursued.

In public procurement, the level of competition (C) (Tavares, 2011) (Tavares, 2015) can be mathematically defined by a simple formula:

$$
\mathrm{C}=\mathrm{N}-1
$$

where $\mathrm{N}$ is the number of economic operators that can present a relevant tender.

There are several ways of reducing $\mathrm{N}$ in competitive procedures with a prior publication of notice such as including too hard conditions for selection, qualification or even too narrow specifications to be fulfilled by the tender disrespecting the competition principle as it has been stated by the European Court of Justice in many cases (see, for instance (Jema Energy v Entreprise, 2017)).

NPWN reduces $\mathrm{N}$ through the number of invited tenderers but the assumption that the degree of competition is always higher for competitive procedures with prior notice than for NPWN or that inviting 1 or more tenderers has the same degree of competition as it has been expressed by juridical authors ${ }^{1}$ (Amaral e Almeida and Sánchez, 2016) just shows not understanding the economic concept of competition.

Furthermore, it should be noted that NPWN includes the case of direct award $(\mathrm{N}=1)$ but it also includes invitations to $\mathrm{N}>1$ economic operators as it is clear from the Article 32 of (European Parliament and the Council of the European Union, 2014a) where the case of $N=1$ is just mentioned in Article $32^{\circ}-2$ b).

The quoted communication (European Commission, 2020a) also explains that $\mathrm{N}$ should be higher than 1 , if possible:

\footnotetext{
1"the contribution of the duty to invite more than one entity to the promotion of competition is utopic" (translation by the author)
} 
"Eventually, even a direct award to a preselected economic operator could be allowed, provided the latter is the only one able to deliver the required supplies within the technical and time constraints imposed by the extreme urgency "

and

"Concretely, the negotiated procedure without publication allows public buyers to acquire supplies and services within the shortest possible timeframe. Under this procedure, as set out in Art. 32 of Directive 2014/24/EU (the 'Directive') (2), public buyers may negotiate directly with potential contractor(s) and there are no publication requirements, no time limits, no minimum number of candidates to be consulted, or other procedural requirements"

These two paragraphs are quite important and consistent as they are both restating the wellknown principle of the Directives: NPWN just can be used in urgent situations already discussed and $\mathrm{N}$ should be higher than 1 whenever such option is compatible with the level of urgency but $\mathrm{N}=1$ can be accepted if just direct award to a pre-selected economic operator will cope with the existing conditions of extreme urgency .

This means that NPWN is available for urgent conditions in an emergency context due to COVID 19 and $\mathrm{N}>1$ should be adopted whenever is possible, but NPWN should be just be:

"used in order to cover the gap until more stable solutions can be found" such as framework contracts for supplies and services, awarded through regular procedures (including accelerated procedures)."

as it is clear in 2.3.4 of (European Commission, 2020a).

Nevertheless, after almost one year of pandemic context it can be concluded that (Lalliot and Yukins, 2020):

"The COVID-19 emergency lasted relatively briefly, allowing time only for surprise and quick reactions. As countries learn to manage in a new post-COVID era, they must also rethink emergency purchasing procedures which are no longer justified in the face of a situation which is admittedly difficult to control but which is no longer unpredictable"

and so it is recommended that (Lalliot and Yukins, 2020):

"new approaches are needed - though ones grounded in traditional norms of transparence, competition and integrity. Public policy should rest on digital tools that allow governments to respond to the exigencies of a crisis and the immediate needs of users, while ensuring transparency and reliability of purchases, and the publicity of operations"

Summing up, the presented guidelines should be considered by the contracting authorities to use the procurement options of type I without disregarding the major value and policy objective of European public policies: setting up competitive public markets.

Thus, the percentage of procurement procedures opened to competition through a contract notice can be a preliminary proxy to quantify the fulfillment of this policy goal and this indicator will be used for the cross State comparative analysis in Section 7.

\section{B) Electronic Public Procurement}

A key instrument to cope with the new challenges of public procurement policies concerns e-public procurement as it helps to form contracts, to support the sustainable development of supply chains, to accelerate procedures and to promote integrity. 
Actually, electronic instruments and e-procurement is mandatory in EU since 2018 (Article $90^{\circ}$ of (European Parliament and the Council of the European Union, 2014a)) and can play a very important role to promote fast acquisitions as well as sustainability and innovation because it may reduce the bureaucratic load (Arantes et al., 2013) (Aguiar Costa et al., 2013), it may facilitate the dissemination of competitions or the request for innovative bids and it allows the implementation of new and innovative procedures (Tavares et al., 2014).

Such positive impacts were estimated for Portugal (Arantes et al., 2013) (Aguiar Costa et al., 2013) which was the first member State to adopt mandatory e-public procurement since 1 November of 2009, and the results were quite positive and relevant to support the deadline of 2018 established by the European Directives on Public Procurement (European Parliament and the Council of the European Union, 2014a).

Furthermore, e-procurement can help to reduce the risks of lack of integrity as it is suggested by (OECD, 2020, page 5 ) as recommended initiatives :

"Using or expanding existing e-procurement platforms to record transactional information on the procurement of emergency items. A database could be created to analyse bidding patterns and identify potential red flags, signalling risks posed to integrity" and

"Creating digital and easily accessible tools to allow the public to track all emergency purchases undertaken in line with emergency procurement measures".

Also, e-public procurement is an essencial condition to apply the proposed procedures explained in C) of this section.

Finally, a special mention about the importance of "digital tools" is also made in the quoted communication:

“(..)In addition: Public buyers may use innovative digital tools (4) to trigger a wide interest among economic actors able to propose alternative solutions(...)Public buyers may also work more closely with innovation ecosystems or entrepreneurs' networks, which could propose solutions"

\section{C) Sustainable and innovative public markets}

During the last decades, the contribution of public procurement to accelerate public policies (Arrowsmith, 2010) (Tavares et al., 2014) has been receiving growing priority as it is clearly expressed by the Recitals $\mathrm{n}^{\circ} 2$ and 47 of (European Parliament and the Council of the European Union, 2014a):

"(2)- Public procurement plays a key role in the Europe 2020 strategy, set out in the Commission Communication of 3 March 2010 entitled 'Europe 2020, a strategy for smart, sustainable and inclusive growth' ('Europe 2020 strategy for smart, sustainable and inclusive growth'), as one of the market-based instruments to be used to achieve smart, sustainable and inclusive growth while ensuring the most efficient use of public funds...."

(47) Research and innovation, including eco-innovation and social innovation, are among the main drivers of future growth and have been put at the centre of the Europe 2020 strategy for smart, sustainable and inclusive growth. Public authorities should make the best strategic use of public procurement to spur innovation. Buying innovative products, works and services plays a key role in improving the efficiency and quality of public services while addressing major societal challenges. It contributes to achieving best value for public money as well as wider economic, environmental and societal benefits in terms of generating new ideas, translating them into innovative products and services and thus promoting sustainable economic growth " 
The study of sustainable and innovative procurement has been treated by Manuals of the European Commission (European Commission, 2016) (European Commission, 2019a) of OECD (OECD, 2015) (OECD, 2017) and by other authors (see, namely (Tavares et al., 2014) (Tavares, 2019)). The application of green public procurement using the life cycle cost as award criterion has been even studied for goods particularly important to cope with COVID19, namely, imaging equipment and computers or monitors (European Commission, 2019b) (European Commission, 2019c).

The procedures already presented in the previous section can be quite useful to "shape markets" as it is recommended by (Mazzucato, 2016) as they set up a stable and adaptive framework for public contracting and also to achieve the public policy goal of promoting sustainable and innovative procurement if.

a) The procedure documents leave significant degrees of freedom to the bidders and introduce incentives to pursue the goals of innovate and to improve sustainability.

b) The award criterion is the Most Economically Advantageous Tender (MEAT) clearly explained and recommended by (European Parliament and the Council of the European Union, 2014a) (Article $67^{\circ}$ ) including the appropriate value functions to model such goals rather than the minimal price under full specification of the contract object which prevents the introduction of such incentives. The Article $68^{\circ}$ (Life-cycle costing) explains the application of MEAT to the life cycle cost criterion which can be also quite important to promote sustainable procurement.

The adoption of the MEAT criterion is not sufficient to promote sustainable and innovative procurement but it is a key necessary condition and therefore the percentage of contracts awarded by this criterion can be a preliminary proxy of the importance given to the achievement of this public policy goal.

This explains why this indicator is used for the cross-State comparative analysis presented in Section7.

Several EU States (OECD, 2020c) are making full use of aggregated and electronic instruments to pursue sustainable procurement strategies based on Central Purchasing Bodies or Central Procurement Agencies as it is the case of Estonia (State Shared Service), Finland (Central Purchasing Body using FAs and DPSs),France (Central Purchasing Body UGAP), Greece (Hellenic Single Public Procurement Authority), Ireland (Office of Governmental Procurement), Italy (Central Purchasing Body, CONSIP),The Netherlands (PIANOo), Poland (Public Procurement Office) and Sweden (Swedish Agency for Public Procurement). The European Commission promoted 3 Joint Procurement Agreements about gloves and surgical gowns (28 February 2020), PPE, ventilators and respiratory equipment (17 March 2020) and laboratory equipment including test kits (19 March 2020).

The development and an innovative application of FA with an electronic catalogue to contract Home Health Respiratory Care services in Portugal implementing the public management concept of Quasi-Market (Vincent-Jones, 2006) and embracing all the main qualified providers is described and discussed by (Tavares and Arruda, 2020). The presented results show how impressive are the advantages achieved in terms of cost reduction, quality of services innovation and sustainability if compared with the traditional approach a series of open or restricted procedures. 
Unfortunately, the number of applications of the Partnership for Innovation is far behind the expected level.

Summing up, the presented options allow a positive answer to the research question addressed by this paper.

\section{A Comparative Analyses across EU}

Health expenditure has been deeply affected by this pandemic through a twofold impact:

a) High reduction of the normal services such as surgeries, urgencies or first appointments as it happened in Portugal where the percentages of reduction were $-58 \%,-44 \%$ and $-40 \%$, respectively during 2020.

b) Urgent and vast need of procurement for items related to COVID19 corresponding the CPV codes 33157400, 33670000, 33631600, 33195110, 35113400, 18424300, 33141420, 33192120, 39330000, 33191000, 18143000, 45215142, 33157110, 33157000, 33694000 according to (Tenders Electronic Daily, 2021).

The number of contract award notices published by TED, between 1/2/2020 and 31/12/2020 and considering the relevant codes related to COVID 19, include more than 4000 contract award notices distributed by different types of procedures and States as it is shown in Table 2:

Table 3- Contract Award Notices [Type of Procedure]

\begin{tabular}{|c|c|c|c|c|c|c|c|c|c|}
\hline & $\begin{array}{c}\text { Negotiated } \\
\text { procedure } \\
\text { without a } \\
\text { call for } \\
\text { competition }\end{array}$ & $\begin{array}{c}\text { Open } \\
\text { procedure }\end{array}$ & $\begin{array}{c}\text { Competitive } \\
\text { procedure } \\
\text { with } \\
\text { negotiation }\end{array}$ & $\begin{array}{l}\text { Restricted } \\
\text { procedure }\end{array}$ & $\begin{array}{c}\text { Accelerated } \\
\text { restricted } \\
\text { procedure }\end{array}$ & $\begin{array}{l}\text { Negotiated } \\
\text { procedure }\end{array}$ & $\begin{array}{c}\text { Innovation } \\
\text { partnership }\end{array}$ & $\begin{array}{c}\text { Contract } \\
\text { award } \\
\text { without } \\
\text { prior } \\
\text { publication }\end{array}$ & Total \\
\hline Austria & 112 & 22 & 4 & & & & & 2 & 140 \\
\hline Belgium & 3 & 31 & 5 & & & & & & 39 \\
\hline Bulgaria & 2 & 98 & & 3 & & 3 & & & 106 \\
\hline Croatia & 13 & 25 & & 1 & & & & & 39 \\
\hline Cyprus & 2 & 1 & & & & & & & 3 \\
\hline Czechia & 11 & 220 & & 43 & & 4 & & 4 & 282 \\
\hline Denmark & 24 & 11 & 2 & 2 & & 1 & & & 40 \\
\hline Estonia & 4 & 17 & & & & & & & 21 \\
\hline Finland & 1 & 21 & 2 & 2 & & & & 3 & 29 \\
\hline France & 104 & 168 & 1 & 1 & & 11 & & 17 & 302 \\
\hline Germany & 129 & 117 & 4 & & & 1 & & 4 & 255 \\
\hline Greece & 2 & 20 & & & & & & & 22 \\
\hline Hungary & 5 & 49 & & & & & & & 54 \\
\hline Ireland & 5 & 8 & & & & 1 & & 1 & 15 \\
\hline Italy & 10 & 57 & & 3 & & & & 4 & 74 \\
\hline Latvia & 4 & 17 & & & & 1 & & & 22 \\
\hline Lithuania & 53 & 155 & & 1 & & & & 1 & 210 \\
\hline Luxembourg & 10 & & & & & & & 2 & 12 \\
\hline Malta & 1 & 3 & & & & & & & 4 \\
\hline Netherlands & 8 & 16 & & 1 & & & & & 25 \\
\hline
\end{tabular}




\begin{tabular}{|c|c|c|c|c|c|c|c|c|c|}
\hline Poland & 9 & 552 & 1 & 4 & 1 & & & & 567 \\
\hline Portugal & 1 & 3 & & & & & & & 4 \\
\hline Romania & 146 & 912 & & 1 & & & & 1 & 1060 \\
\hline Slovakia & 10 & 40 & & 6 & & & & & 56 \\
\hline Slovenia & 6 & 83 & & 3 & & & & & 92 \\
\hline Spain & 55 & 110 & 2 & & & 2 & & 7 & 176 \\
\hline Sweden & & 72 & & & & 2 & & & 74 \\
\hline $\begin{array}{c}\text { United } \\
\text { Kingdom }\end{array}$ & 357 & 33 & & 2 & & & 1 & 17 & 410 \\
\hline Total & 1087 & 2861 & 21 & 73 & 1 & 26 & 1 & 63 & 4133 \\
\hline
\end{tabular}

The total number of the contracts is denoted by $\mathrm{CT}$ and the sum of the first and last columns correspond to contracts without prior notices $(\mathrm{CWN})$. Thus, $\mathrm{CT}=\mathrm{CWN}+\mathrm{CC}$, where $\mathrm{CC}$ is the number of contracts with prior notice.

The most common procedure is the open procedure as it could be expected, including a significant percentage of competitions opened within a framework agreement.

The distribution of contract award notices per State and award criterion can also be studied considering the minimal price criterion (NP) and MEAT (Most economically advantageous tender) criterion (NQ) (Table 3)

Table 4- Contract Award Notices [Award Criterion]

\begin{tabular}{|c|c|c|}
\hline Country & Minimal Price & MEAT \\
\hline Austria & 109 & 31 \\
\hline Belgium & 6 & 33 \\
\hline Bulgaria & 99 & 7 \\
\hline Croatia & 4 & 35 \\
\hline Cyprus & 3 & 0 \\
\hline Czechia & 218 & 64 \\
\hline Denmark & 25 & 15 \\
\hline Estonia & 12 & 9 \\
\hline Finland & 12 & 17 \\
\hline France & 128 & 174 \\
\hline Germany & 146 & 109 \\
\hline Greece & 17 & 5 \\
\hline Hungary & 19 & 35 \\
\hline Ireland & 8 & 7 \\
\hline Italy & 45 & 29 \\
\hline Latvia & 20 & 2 \\
\hline Lithuania & 208 & 2 \\
\hline Luxembourg & 1 & 11 \\
\hline Malta & 4 & 0 \\
\hline Netherlands & 13 & 12 \\
\hline & & \\
\hline & & \\
\hline
\end{tabular}




\begin{tabular}{|c|c|c|}
\hline Poland & 155 & 412 \\
\hline Portugal & 4 & 0 \\
\hline Romania & 862 & 198 \\
\hline Slovakia & 56 & 0 \\
\hline Slovenia & 84 & 8 \\
\hline Spain & 77 & 99 \\
\hline Sweden & 62 & 12 \\
\hline United Kingdom & 342 & 68 \\
\hline Total & 2739 & 1394 \\
\hline
\end{tabular}

The presented results allows the estimation of the two proxy indicators already presented to describe competitiveness and necessary conditions for sustainability and innovation: the Competition Index (CI) and the Price Quality Index (PCI).

Also, these data allows the estimation of how frequent is the adoption of procurement procedures for contracts with a value equal or higher than the EU thresholds which will be denoted by Contracting Intensity Index (CII).

\section{A- COVID19 Contracting Intensity Index (CII)}

This indicator is defined by the percentage ratio between CT and the total number of citizens that were infected by COVID19 (total cases/100) expressing the preference by each State to award contracts with a value higher than the EU thresholds. This indicator expresses the combined effect of two different factors.

a) the need to buy because some States may be more or less equipped to cope with the pandemic;

b) the organization of public procurement more or less based on contracts with a value equal or higher than the EU thresholds. Obviously, those States preferring procurement based on contracts with a value lower than the thresholds are contributing less to the single market than those with alternative policies.

The results are presented in Figure 1:

Figure 1 - Contracting Intensity Index

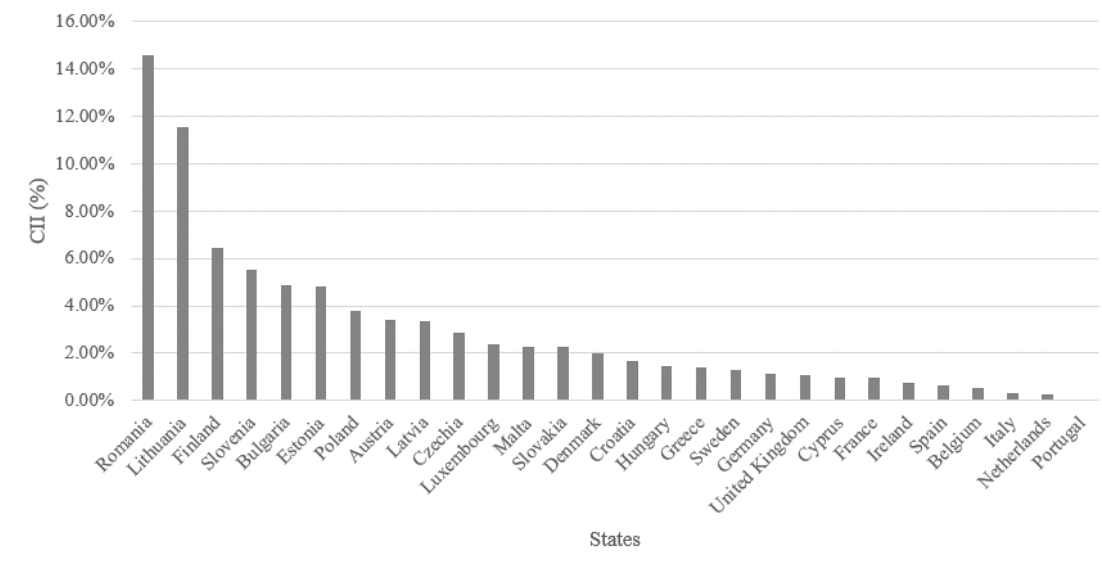




\section{B- The Competition Index (CI)}

This indicator can be considered as a proxy of how the goal of contributing to competitive public markets is considered by each State and it may be defined by the ratio CC/(CWN + CC) representing the percentage of contracts opened to competition through TED and its presented in Figure 2:

Figure 2- Competition Index

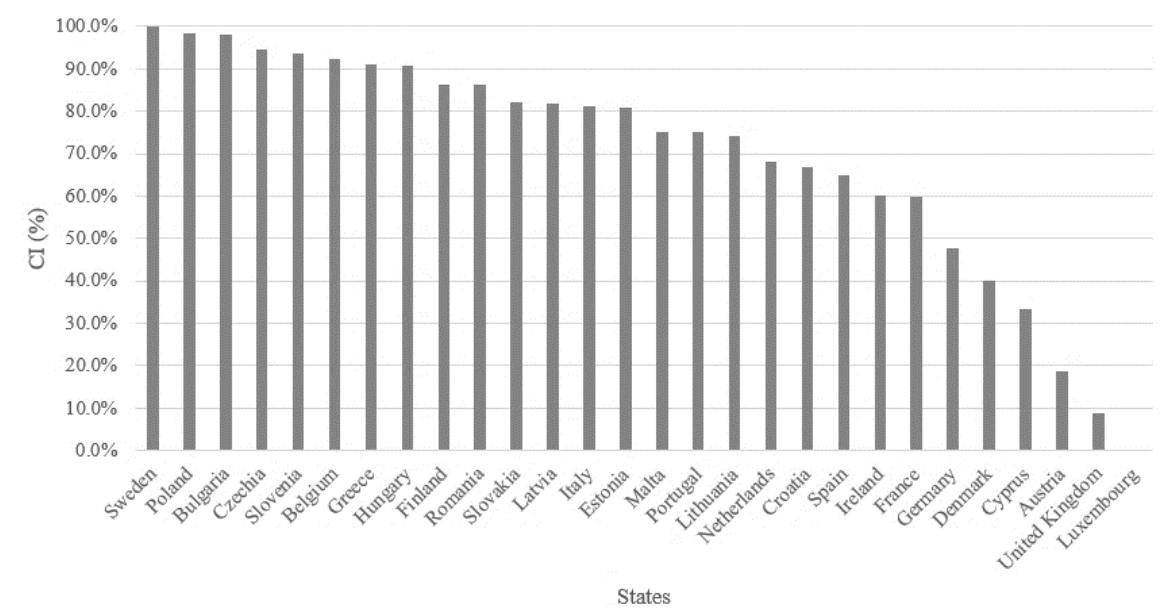

\section{C- Price Quality Index (PQI)}

As it was explained in the Section, the promotion of sustainability and innovation requires that the procurement procedure will allow degrees of freedom to the bidder so that he can develop innovative solutions and can adopt stable strategies to supply demand during long periods. Thus, a proxy of a necessary condition to pursue such goal may be expressed by an indicator defined by the ratio $\mathrm{NQ} /(\mathrm{NP}+\mathrm{NQ})$ representing the percentage of contracts adopting the MEAT ("Most Advantageous Economically Tender ") criterion and presented in Figure 3

Figure 3 - Price Quality Index

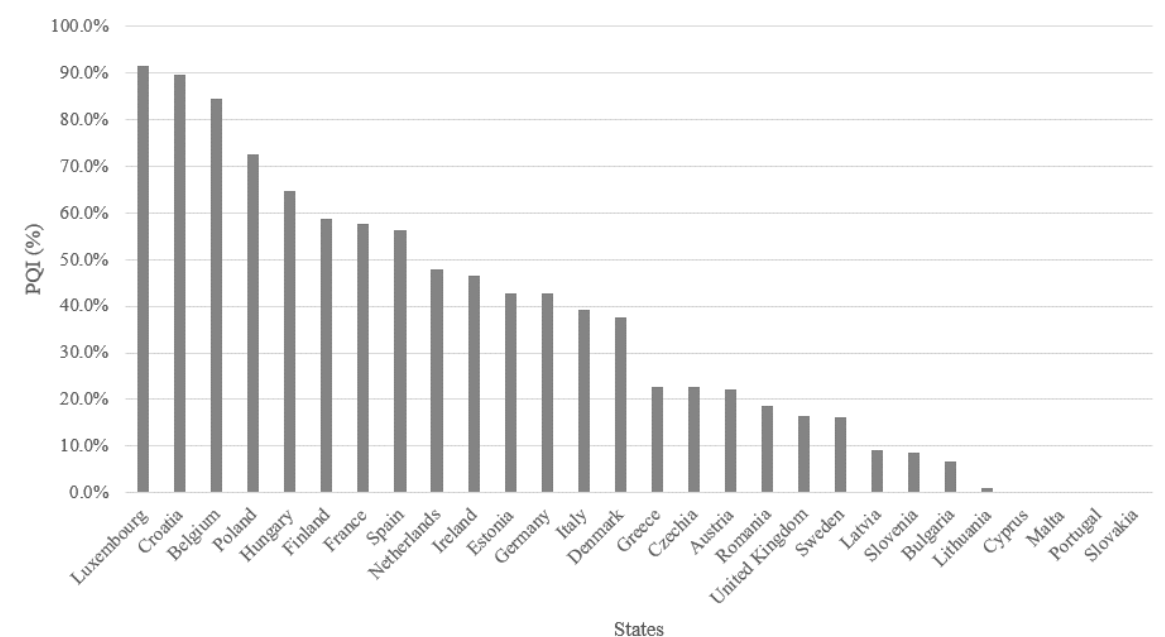

Several comments can be made: 
a) 14 States award more than 30\% of contracts using MEAT award criterion :Luxembourg, Croatia, Belgium, Poland, Hungary, Finland, France, Spain, Netherlands, Ireland, Estonia, Germany, Italy and Denmark.

b) All but six States (Luxembourg, UK, Austria, Cyprus, Denmark, Germany) award more than $50 \%$ of the contracts with a value equal or higher than the thresholds and publishing a contract notice.

c) All these indicators express quite a high diversity of procurement options and patterns made by the member States to procure goods and services to fight COVID 19 which is confirmed by their estimated coefficient of variation (standard deviation over mean) which is particularly high for CII and PQI: $\mathrm{CV}(\mathrm{CII})=1.11 ; \mathrm{CV}(\mathrm{CI})=0.39: \mathrm{CV}(\mathrm{PQI})=0.81$

d) PQI can be described by a linear function with equation $\mathrm{PQI}\left({ }^{\mathrm{n}}\right){ }^{=} 0.85^{-} 0.0345 \mathrm{n}$ (with $\mathrm{R}^{2}=$ 0.9599 ) being $n$ the index ordering the States ( $n=1$ for Luxembourg and $n=28$ for Slovakia) but the other indicators have a non-linear behavior.

Furthermore, a few more specialized comments can be made:

a) The evident diversity of openness to competition and to assess quality as an award criterion shows that this substantial increase of public acquisitions may not have the optimal impacts in these public markets in terms of quality improvement and prices stabilization.

b) COVID 19 has also justified public procurement besides the CPV codes selected by TED such as the acquisition of information systems and computers or the installation and management of call centers to guide citizens in terms of their symptoms.

c) Central Purchasing Bodies could be expected to correspond to a large share of notices concerning the CPV codes selected by TED and related to competitive procedures but that is not the case. There is even the notorious absence of central purchasing bodies such as CONSIP in Italy or SPMS (Health Central Purchasing Body) in Portugal as they have not sent a single notice.

d) An unusual DPS was opened for public works concerning the development and renewal of housing for a Scottish region during 5 years and with a value of $40 \mathrm{M}$ GBP.

e) A competitive dialogue concerning medical and surgical materials was opened by an important hospital in Dublin.

f) In the case of Portugal (Tribunal de Contas, 2020) from March,16,2020 until March, 31, 2020, 55 public contracts were awarded using the COVID19 TED codes and each one with a value higher than $1 \mathrm{M}$ euros. The total awarded value was $158 \mathrm{M}$ euros and $56 \%$ of procedures adopted either NPWN or Direct Award meaning quite a low value for TI. Furthermore, and unfortunately, most of these award contract notices were not sent to TED but, quite surprisingly, it seems that no sanctions will be applied.

\section{The Case of Portugal}

\subsection{Approach}

Most Governments are aware that they have approved an web of cumbersome and complex legal rules for public procurement and so they tend to believe that the magic solution to fight pandemics is relaxing some of these complexities facilitating the use of NPWN (or even just the use of direct 
award as it happens in Portugal). This "mystic" believe shows deep ignorance about the disruptive and turbulent changes in public markets due to war conditions as it happens with COVID 19 and so the major needs concerning supply chains monitoring and their longer term consolidation , promoting the innovation and optimization of sourcing through aggregation and electronic instruments are forgotten.

Portugal is an example of such policy, as since the outbreak of COVID 19, the Portuguese Government approved 12 major legal acts (Tavares, 2020) from 24 March until 29 May 2020 corresponding to an average of 1.5 legal act per week just oriented to accelerate procedures. According to the comprehensive analysis by (Raimundo, 2020) the main decree-law (Presidência do Conselho de Ministros, 2020a) was already amended 15 times which means that the emergency regime concerning contracts directly related to fight the pandemic COIVD19 introduces additional doubts and complexity.

Unfortunately the Portuguese tradition of preparation of the legal framework does not follow the recommendations of OCDE (OECD, 2020d) and no background interdisciplinary studies are known to have been used to support the adopted juridical options explaining why no analysis of the diversity of procurement needs was carried out and why the multiple and complex legal measures had the major objective of making procedures more expeditious

Unfortunately, the published acts, namely (Presidência do Conselho de Ministros, 2020a), do not express any concern with the Type II needs and just includes measures to accelerate procedures based on urgency due to COVID 19 for contracts concerning meaning that no analysis of the sourcing challenges including innovation and rationalization were considered. Therefore, the paragraphs quoted in Sections 3 and 5 from (European Commission, 2020a) as well as important contributions focusing the need to cope with the needs of Type II, were ignored by the approved legal act.

Other several interesting papers about public contracting under COVID19 were published by Portuguese legal experts but they just tend to discuss the new regime and so no study is included about the type II needs or the electronic instruments for aggregated procurement (Pereira, 2020) (Azevedo, 2020) (Brito, 2020) (Raimundo, 2020) (Sánchez, 2020).

\subsection{Formation of contracts}

The approved act (Presidência do Conselho de Ministros, 2020a) concerns the COVID19 contracts and includes the Article $2^{\circ}-1$ confirming the possibility of using NPWN for high value contracts based on urgency already stated by the normal public contracts law (Planeamento e das Infraestruturas, 2017) but the Article 27-A of (Planeamento e das Infraestruturas, 2017) is revoked by the Article $\mathrm{n}^{\circ} 2^{\circ}-3$. The Article $27^{\circ}-\mathrm{A}$ is very important because it states that invitation should adopt $\mathrm{N}^{2} 3$ economic operators whenever it is feasible ("consulta prévia"). Therefore, public contracting authorities can now, under the new regime, award contracts with a value higher than the Directives thresholds by direct award to a preselected economic operator due to urgency related to COVID 19 even if invitation to more than one economic operator is compatible with the urgency conditions. The authors have no doubts that this new rule:

a) Does not promote the respect the Directives principles ruling the adoption of NPWN for N=1 only if $\mathrm{N}>1$ is not feasible as it was shown before. 
b) Will reduce the value for money of acquired goods and services according to the principles of Market Economy.

Furthermore, this legal act has no time limit for its application (months, years?) and allows the disrespect of existing framework agreements (Article $2^{\circ}-7$ ) contributing to the fragmentation of public procurement.

Additional legislation (namely (Assembleia da República, 2020)) has contributed to a more expeditious implementation of award decisions (Raimundo, 2020) exempting the contracts formed under the act (Presidência do Conselho de Ministros, 2020a) from the need to get an ex-ante compliance declaration ("visto prévio") by Tribunal de Contas (equivalent to the English National Audit Office).

The communication between contracting authorities and economic operators should be based on electronic platforms according to the existing Code of Public Contracts (Planeamento e das Infraestruturas, 2017) to fulfill the requirements of integrity and confidentiality set up by the Article $21^{\circ}-3$ of (European Parliament and the Council of the European Union, 2014a):

"In all communication, exchange and storage of information, contracting authorities shall ensure that the integrity of data and the confidentiality of tenders and requests to participate are preserved."

However, invitation procedures are exempting from this rule because the $\operatorname{Art}^{\circ} 115-1 \mathrm{~g}$ ) allows the use of other "electronic transmission means" which means that common e-mail can be used.

Probably, this exemption was justified in terms of the lower value of contracts formed by NPWN but its generalization to high value contracts should justify the mandatory use of an electronic platform. Unfortunately, such new rule is not included and so doubts about the compliance with the principles of integrity and confidentiality for contracts under the Directives regime can be raised if common email is adopted.

As it could be expected, the execution results justify serious concerns as it is already shown by the thorough report of Tribunal de Contas showing that more than $300 \mathrm{M}$ euros of goods and services were contracted by direct award since March to September (Tribunal de Contas, 2020). Such acquisitions include the same items with high fluctuations of the unit price (from 1 to 2.6) and equipment that cannot be used as it was mentioned before.

Also, more than 96\% of COVID 19 contracts awarded by Portuguese municipalities until September 2020 have adopted the direct award procedure ( TC, 2020a).

In the Health sector, since March 2020, it should be noted that no competitive procedures with prior notice were published by Health Central or Regional Contracting authorities in TED, including SPMS, confirming the previous doubts and the potential of the instruments of the aggregated and electronic procurement is ignored. Actually, common goods as masks or gowns were not acquired through centralized procedures increasing inefficiency and disparities ( Martins, 2021).

\subsection{Contract Execution}

The challenges of COVID19 are also quite relevant for the regime of execution of public contracts, namely about the possibility of introducing modifications during their execution (see the interesting paper by (Almeida, 2019)) but the published legislation does not introduce additional 
flexibility or additional mechanisms for mediation and arbitration in COVID 19 contracts. Such changes are particularly important because the Portuguese law is more restrictive about the introduction of such modifications than the Directives(Tavares, 2017) (Tavares, 2019). However, the quoted legal act includes positive changes about the possibility of contracting authorities making advanced payments (Article $2^{\circ}-6$ ) avoiding the assumptions ruled by the normal law (Article $292^{\circ}$ of (Planeamento e das Infraestruturas, 2017)) ${ }^{2}$.

Another legal act (Presidência do Conselho de Ministros, 2020b) was approved about the reposition of the financial balance of the long term contracts due to COVID19, namely concessions and public private partnerships, with the objective of allowing the extension of contracts but excluding financial compensations by the State.

\subsection{Additional developments and comments}

In the end of 2020, a new law was approved and will probably be promulgated by the President of Republic in coming weeks defining new simplified and diversified regimes for public procurement for several domains:

a) related to contracts funded by European Funds (A).

b) related to contracts concerning the social and economic recovery defined by (Presidência do Conselho de Ministros, 2020c) (B).

c) related to the digital transition defined by (Presidência do Conselho de Ministros, 2020d) (C).

These two Resolutions include long lists of topics some of them with unclear definitions and even some of them with overlapping domains.

Therefore, on 2021 the public procurement framework will include 3 different regimes:

a) normal law (Planeamento e das Infraestruturas, 2017) ,N .

b) Urgency due to COVID19 (Presidência do Conselho de Ministros, 2020a) and other acts ,U.

c) Without time limit and according to new legal act devoted to the cases A, B and C.

Therefore, in many cases, the contract object may fulfill the conditions concerning $U$ and (A or B or C) as it happens in the example of acquiring a new medical information system using EU funds to monitor COVID 19: it fulfills the COVID19 urgency, it is supported by EU funds, it is included in the list of B and, finally, it is an instrument of Digital Transition (C). In such cases, the public contracting authorities have a "buffet" of regimes of Public Contracts Law and they can select one of them.

The author has no doubts that this amazing proliferation of regimes with fuzzy borders will be treated through quite interesting legal analyses by excellent Portuguese experts but also that it

\footnotetext{
2 *This article sets several assumptions (in Portuguese, "pressupostos") and the restriction of such advanced payments not exceeding $30 \%$ of the contract price but the new legal act exempts the contracting authority of respecting such assumptions. Thus, doubts may be raised about the duty of respecting or not the limit of $30 \%$ because the concepts of restriction and assumption are different. However, a more liberal interpretation of this Article allows exceeding such limit (Raimundo, 2020).
} 
will contribute to complexify the Portuguese legal framework for public procurement rather than contributing for its simplification and therefore increased litigation can be expected.

Summing up, the authors have shown in this paper that the Portuguese legal framework for COVID 19 procurement:

a) has just considered urgent needs;

b) do not promote the full compliance with the principles of competition and transparency of the Directives;

c) introduces a web of complexities through different overlapping exceptional regimes with fuzzy boundaries, instead of simplifying the normal regime;

d) facilitates the rejection of aggregated instruments as framework agreements;

e) keeps allowing the use of common email as mean of communication between contracting authorities and economic operators to form public contracts with a value above the Directive thresholds and so the compliance with the principles of integrity and confidentiality may not be guaranteed.

Furthermore, the emergency regime legally approved has no time limit for its application contradicting the wise recommendations based on multiple evidences (Lalliot and Yukins, 2020):

"As countries learn to manage in a new post-COVID era, they must also rethink emergency purchasing procedures which are no longer justified in the face of a situation which is admittedly difficult to control but which is no longer unpredictable. The return to normal purchasing procedures is also now becoming an issue: while many countries have enacted exceptional time-bound legislation, others have not set any terminal dates for their "emergency" contracting rules which avoid traditional procurement norms."

\section{Final Remarks}

Governments have plans, institutions and budgets to cope with emergent and unexpected events but they tend to be designed to protect citizens and communities from sudden and tragic disruptions such as an earthquake, a tsunamis or an wild fire, rather than from a tragic but long lasting threat as it happens with pandemic COVID19.

The previous equivalent pandemic often called "pneumonic" or "Spanish flu" lasted for 2 years (1918-1920) and killed more than 3\% of the population in several countries (Nunes et al., 2018) but the new scientific and technologic advances are supporting hopes that through massive vaccination, this pandemic will fade away sooner but its real duration is still a very uncertain parameter.

Unfortunately, this uncertain long term duration of COVID19 is not being well coped by the public policies adopted by many Governments on public procurement not just because they have not promoted preventive procurement but also because they tend to adopt myopic options following the paradigm of "buying fast". Unfortunately, such options based on the lack of coordinated and centralized procurement and on the repetitive use of NPWN to buy "fast" do not help to improve the supply chains and reduce sustainability and innovation as well as the value for money besides increasing the risk of lack of integrity.

Conversely to such myopic approach, the adoption of strategic policy lines supporting innovative and sustainable public procurement and respecting the principles of transparency and competition 
has been shown to be the most appropriate approach stemming from the evidences already available from different public markets.

In this paper it is also shown that the EU legal framework includes the appropriate instruments to implement these policy lines giving a positive answer to the research question addressed herein and therefore the rules of the European legal framework cannot be used as an excuse for Governments adopting myopic decisions rather than strategic policies.

The TED data about COVID19 is analyzed and three indices are proposed to have a comparative perspective across EU: contracting intensity, competitiveness and price-quality evaluation as useful proxy indicators of how far are the States pursuing the goals of achieving competitive public markets and necessary conditions for sustainability and innovation. These results confirm the high diversity of policies between States and also that, quite unfortunately, the duty of publishing the award contract notice is not always respected.

The case of Portugal is also studied showing that it is an illustration of the discussed shortcomings and explaining why it fails to be the best example of compliance with the institutional principles governing public procurement in EU.

Finally, a word should be added about this tragic pandemic as an opportunity to reform Governments. In a context of disruptive events as it is the case of COVID19, the Governmental ability to change following the paradigm of adaptive governance (Eshuis and Gerrits, 2021) is quite critical to make use of such opportunity and the reshaping of public procurement can be a very important element to redesign Governmental structures, policies and processes as it has been recommended by many authors (see, e.g. (Ramalingam and Prabhu, 2020) (Phillips et al., 2007).

\section{References}

Ackoff, R.L., 1974. Redesigning the Future: a Systems Approach to Societal Problems, A WileyInterscience publication. Wiley.

Aguiar Costa, A., Arantes, A., Valadares Tavares, L., 2013. Evidence of the impacts of public eprocurement: The Portuguese experience. J. Purch. Supply Manag. 19, 238-246. https://doi.org/10.1016/j.pursup.2013.07.004

Allen, R.G.D., 1936. Professor Slutsky's Theory of Consumers' Choice. Rev. Econ. Stud. 3, 120129 .

Almeida, M.A., 2019. Sobre os limites à modificação objetiva dos contratos administrativos. Rev. dos Contratos Públicos 19, 23-40.

Amaral e Almeida, J., Sánchez, P.F., 2016. Comentários ao Anteprojeto de Revisão do Código dos Contratos Públicos. Sérvulo.

Arantes, A., Aguiar Costa, A., Tavares, L.V., 2013. The evaluation of mandatory e-public procurement in portugal: perceptions and results of the national survey (2010-2012), in: Tavares, L.V. (Ed.), Proceedings of the 1st European Conference on E-Public Procurement (ECPP): E-Public Procurement in Europe: Public Management, Technologies and Processes of Change. OPET, Lisbon, pp. 63-74.

Arrowsmith, S., 2010. Horizontal policies in public procurement: a taxonomy. J. Public Procure. 10, 149-186. https://doi.org/10.1108/JOPP-10-02-2010-B001 
Assembleia da República, 2020. Lei n. ํ 1-A/2020. Diário da República 56/2020, 9-(2)-9-(5).

Azevedo, P.S., 2020. Ensaio sobre a Contratação Pública Pandémica. Rev. da Contratação Pública $24,215-246$.

Brito, M.L., 2020. Impacto da pandemia Covid-19 na execução dos contratos administrativos. Rev. da Contratação Pública 24, 279-304.

Broms, R., Dahlström, C., Fazekas, M., 2019. Political Competition and Public Procurement Outcomes. Comp. Polit. Stud. 52, 1259-1292. https://doi.org/10.1177/0010414019830723

Caldwell, N., Walker, H., Harland, C., Knight, L., Zheng, J., Wakeley, T., 2005. Promoting competitive markets: The role of public procurement. J. Purch. Supply Manag. 11, 242-251. https://doi.org/https://doi.org/10.1016/j.pursup.2005.12.002

ClientEarth, 2011. Briefing No. 3: The guiding principles of public procurement transparency, equal treatment and proportionality - Identifying Opportunities for Sustainable Public Procurement Briefing Series.

DeLeon, P., Vogenbeck, D.M., 2007. The Policy Sciences at the Crossroads, in: Handbook of Public Policy Analysis. Routledge, pp. 3-14.

Dror, Y., 2017. Policymaking under Adversity. Routledge.

Dunn, W.N., 2015. Public Policy Analysis. Routledge.

Edquist, C., Hommen, L., Tsipouri, L., Tsipouri, L.J., 2000. Public Technology Procurement and Innovation, Economics of Science, Technolo. Springer US.

Eshuis, J., Gerrits, L., 2021. The limited transformational power of adaptive governance: a study of institutionalization and materialization of adaptive governance. Public Manag. Rev. 23, 276296. https://doi.org/10.1080/14719037.2019.1679232

European Commission, 2020a. Communication from the Commission Guidance from the European Commission on using the public procurement framework in the emergency situation related to the COVID-19 crisis 2020/C 108 I/01. Off. J. Eur. Union 1-5.

European Commission, 2020b. Communication from the Commission Temporary Framework for State aid measures to support the economy in the current COVID-19 outbreak 2020. Off. J. Eur. Union 1-9.

European Commission, 2019a. Commission notice "Guidance on innovation procurement."

European Commission, 2019b. User Guide to the Life Cycle Costing Tool for Green Public Procurement of Imaging Equipment.

European Commission, 2019c. User Guide to the Life Cycle Costing Tool for Green Public Procurement of Computers and Monitors.

European Commission, 2016. Buying green handbook - Green Public Procurement - Environment - European Commission. https://doi.org/10.2779/246106

European Parliament and the Council of the European Union, 2014a. Directive 2014/24/EU of the European Parliament and of the Council of 26 February 2014 on public procurement and repealing Directive 2004/18/EC. Off. J. Eur. Union L094, 65-242. 
European Parliament and the Council of the European Union, 2014b. Directive 2014/25/EU of the European Parliament and of the Council of 26 February 2014 on procurement by entities operating in the water, energy, transport and postal services sectors and repealing Directive 2004/17/EC. Off. J. Eur. Union L094, 243-374.

European Union, 2012. Treaty on European Union and the Treaty on the Functioning of the European Union. Off. J. Eur. Union C326, 0001-0390.

Expresso, 2021. Computadores chegam às escolas a "conta-gotas." Expresso.

Fischer, F., Miller, G.J., Sidney, M.S., 2017. Handbook of Public Policy Analysis: Theory, Politics, and Methods, Public Administration and Public Policy. Routledge.

Gaspar, V., Lam, W.R., Raissi, M., 2020. Fiscal Policies to Contain the Damage from COVID-19 [WWW Document]. IMFBLOG. URL https://blogs.imf.org/2020/04/15/fiscal-policies-to-containthe-damage-from-covid-19/

Gerbrandy, A., Janssen, W.A., Thomsin, L., 2019. Shaping the Social Market Economy After the Lisbon Treaty: How 'Social' is Public Economic Law? Utr. Law Rev. 15, 32. https://doi.org/10.18352/ulr.509

Gomes, P.C., 2021. EU Public Procurement and Innovation: The Innovation Partnership Procedure and Harmonization Challenges. Edward Elgar Publishing Limited.

Hunt, S.D., 2000. A General Theory of Competition: Resources, Competences, Productivity, Economic Growth, A General Theory of Competition: Resources, Competences, Productivity, Economic Growth. SAGE Publications.

Jema Energy v Entreprise, 2017. Case T-668/15, ECLI:EU:T:2017:796.

Lalliot, L.F., Yukins, C.R., 2020. COVID-19: Lessons learned in public procurement. Time for a new normal? Concurrences 46-58.

Lasswell, H., 1951. Value-oriented policy orientation, in: Lexner, D., Lasswell, H. (Eds.), The Policy Sciences. Stanford University Press.

Le Grand, J., Bartlett, William, 1993. The Theory of Quasi Markets, in: Le Grand, J., Bartlett, Will (Eds.), Quasi Markets an Social Policy. Macmillan International Higher Education, London, pp. 13-34.

Mazzucato, M., 2016. From market fixing to market-creating: a new framework for innovation policy. Ind. Innov. 23, 140-156. https://doi.org/10.1080/13662716.2016.1146124

Nunes, B., Silva, S., Rodrigues, A., Roquette, R., Batista, I., Rebelo-de-Andrade, H., 2018. The 1918-1919 Influenza Pandemic in Portugal: A Regional Analysis of Death Impact. Am. J. Epidemiol. 187, 2541-2549. https://doi.org/10.1093/aje/kwy164

OECD, 2020a. Public Procurement and Infrastructure Governance: Initial policy responses to the Coronavirus (COVID-19)crisis.

OECD, 2020b. OECD Policy Responses to Coronavirus (COVID-19) - Public integrity for an effective COVID-19 response and recovery. 
OECD, 2020c. Stocktaking Report on Immediate Public Procurement and Infrastructure Responses to COVID-19.

OECD, 2020d. Recommendation of the Council on Improving the Quality of Government Regulation.

OECD, 2017. Procurement for Innovation: Good practices and strategies.

OECD, 2015. Going Green: Best Practices for Sustainable Procurement.

OECD, 2011. Demand-side Innovation Policies.

Pereira, P.M., 2020. Procedimentos fechados no contexto de emergência e de estabilização. Rev. da Contratação Pública 24, 194-214.

Peres, R., 2021. Covid 19 - Procurement at the Centro Hospitalar Lisboa Oriental.

Phillips, W., Caldwel, N., Callender, G., 2007. Public procurement A pillar of good governance?, in: Harland, C., Telgen, J., Thai, K. V, Callender, G., Knight, L., Mcken, K. (Eds.), Public Procurement International Cases and Commentary. Routledge, pp. 138-148. https://doi.org/10.4324/NOE0415394048.ch10

Piga, G., Treumer, S., 2013. The Applied Law and Economics of Public Procurement, The Applied Law and Economics of Public Procurement. Taylor and Francis. https://doi.org/10.4324/9780203096314

Planeamento e das Infraestruturas, 2017. Decreto-Lei n. ${ }^{\circ}$ 111-B/2017. Diário da República 168/2017, 5250-(1894)-5250-(2052).

Prahalad, C.K., Ramaswamy, V., 2004. The Future of Competition: Co-Creating Unique Value With Customers. Harvard Business Review Press.

Presidência do Conselho de Ministros, 2020a. Decreto-Lei n. ${ }^{\circ}$ 10-A/2020. Diário da República 52/2020, 22-(2)-22-(13).

Presidência do Conselho de Ministros, 2020b. Decreto-Lei n. ${ }^{\circ}$ 19-A/2020. Diário da República $85 / 2020$.

Presidência do Conselho de Ministros, 2020c. Resolução do Conselho de Ministros n. ${ }^{\circ}$ 41/2020. Diário da República n. ${ }^{\circ} 110-\mathrm{A} /$.

Presidência do Conselho de Ministros, 2020d. Resolução do Conselho de Ministros n. ${ }^{\circ}$ 30/2020. Diário da República n. ${ }^{\circ}$ 78/202.

Público, 2020. Ventiladores chineses custaram 1,3 milhões e nunca funcionaram. Público.

Raimundo, M.A., 2020. Covid 19 e contratação pública: O Regime Excepcional do Decreto-Lei n1. ${ }^{\circ}$ 10-A/2020, de 13 de Março. Rev. da Ordem dos Advogados ROA I/II.

Raimundo, M.A., 2012. Catástrofes naturais e contratação pública, in: Gomes, C.A. (Ed.), Direito(s) Das Catástrofes Naturais. Almedina.

Ramalingam, B., Prabhu, J., 2020. Innovation, development and COVID-19: Challenges, opportunities and ways forward. 
Sanchez-Graells, A., 2020. More On Covid-19 Procurement In The Uk And Implications For $\begin{array}{llll}\text { Statutory Interpretation } & \text { [WWW URL }\end{array}$ https://www.howtocrackanut.com/blog/2020/4/6/more-on-covid-19-procurement-in-the-uk-andimplications-for-statutory-interpretation

Sanchez-Graells, A., 2018. Competition and Public Procurement. J. Eur. Compet. Law Pract. 9, 551-559. https://doi.org/10.1093/jeclap/lpy060

Sanchez Graells, A., 2016. Truly Competitive Public Procurement as a Europe 2020 Lever: What Role for the Principle of Competition in Moderating Horizontal Policies? Eur. Public Law 22, 377394.

Sanchez Graells, A., 2015. Public Procurement and the EU Competition Rules, 2nd ed. Hart Publishing, United Kingdom.

Sánchez, P.F., 2020. Medidas excecionais de Contratação Pública e de autorização de despesa pública para resposta à epidemia SARS -Cov -2. Sérvulo Publ.

Schultz, J., Søreide, T., 2008. Corruption in emergency procurement. Disasters 32, 516-536. https://doi.org/https://doi.org/10.1111/j.1467-7717.2008.01053.x

Simeon, R., 1976. Studying Public Policy. Can. J. Polit. Sci. / Rev. Can. Sci. Polit. 9, 548-580.

Tavares, J.F.F., 2020. O regime jurídico-financeiro no estado de exceção - a necessidade de "fastlaw" para situações emergentes, in: Gomes, C.A., Pedro, R. (Eds.), O Direito Administrativo de Necessidade e de Excepção. AAFDL, Lisbon, pp. 905-922.

Tavares, L.V., 2019. Public Procurement Innovation: A cultural challenge. Eur. J. Public Procure. Mark. 2, 7-18.

Tavares, L.V., 2018. Transposition of the 2014 European Directives on Public Procurement by Portugal: woes and expectations. Eur. J. Public Procure. Mark. 1, 37-47.

Tavares, L.V., 2017. O Guia da Boa Contratação Pública: as Diretivas de 2014 e o Decreto-Lei 111$\mathrm{B} / 2017$. OPET.

Tavares, L.V., 2015. A Transposição da Nova Diretiva 2014/24/EU relativa aos processos de aquisição de bens, serviços e obras baseados em contratos públicos: Concorrência e Inovação. Rev. do Trib. Contas 63/64, 67-100.

Tavares, L.V., 2013. An essay on the future of e-public procurement in Europe: 2015-2025, in: Tavares, L.V. (Ed.), Proceedings of the 1st European Conference on E-PublicP Rocurement (ECPP): E-Public Procurement in Europe: Public Management, Technologies and Processes of Change. OPET.

Tavares, L.V., 2011. A melhoria da contratação pública e o memorando de entendimento: o desafio da competitividade. Rev. do Trib. Contas 55/56, 21-48.

Tavares, L.V., Arruda, P., 2020. The Proposed Methodology for Assessing the Contractual Performance of Home Respiratory Care. Lisbon.

Tavares, L.V., Correia, F.N., Themido, I.H., Oliveira, R.C., 1997. Investigação Operacional. Mc Graw-Hill. 
Tavares, L.V., Medeiros, R., Coelho, D., 2014. The new Directive 2014/24/EU on Public Procurement. OPET.

Tenders Electronic Daily, 2021. COVID-19-related tenders [WWW Document]. URL https://simap.ted.europa.eu/web/simap/covid-related-tenders

Townsend, H., 1980. Price theory: selected readings, 2nd ed. ed. Penguin Harmondsworth, Middlesex, England.

Tribunal de Contas, 2020. Acompanhamento dos Contratos Abrangidos pelo Regime de Exceção Previsto na Lei n. ${ }^{\circ}$ 1-A/2020, incluindo os isentos de Fiscalização Prévia - Relatório Intercalar.

Vincent-Jones, P., 2006. The New Public Contracting: Regulation, Responsiveness, Relationality, The New Public Contracting: Regulation, Responsiveness, Relationality. Oxford University Press. https://doi.org/10.1093/acprof.oso/9780199291274.001.0001

World Health Organization, 2020. Shortage of personal protective equipment endangering health workers worldwide [WWW Document]. URL https://www.who.int/news/item/03-03-2020shortage-of-personal-protective-equipment-endangering-health-workers-worldwide

Yukins, C.R., Schwartz, J.I., 2005. Katrina's Continuing Impact on Procurement - Emergency Procurement Powers in H.R. 3766 Procurement Powers in H.R. 3766. Gov. Contract. 47, 1-6. 